\title{
Biodiesel from Microalgae: Advantages and Future Prospective
}

\author{
Mostafa M. El-Sheekh \\ Botany Department, Faculty of Science, Tanta University, Tanta, Egypt.
}

\section{Introduction}

Biofuel is considered as a solution to substitute petroleum fuel and to reduce the carbon dioxide emissions contributing to global warming. The most known biofuels used are biodiesel, bioethanol, and biohydrogen extracted from biomass. For a long time, these biofuels were produced from edible crops that compete with the food of humans and animals. Therefore, research is focused worldwide on alternative biomass sources. Scientists are looking for innovative biofuel feedstocks such as agricultural wastes, algae, and jatropha. The first generation of biodiesel mainly depended on vegetable oils for conversion to methyl esters and glycerol. In Johannesburg, South Africa, the 2002 World Summit on Sustainable Development pledged to promote renewable energy sources. At the United Nations Climate Change Conference (COP21) in Paris in 2015, 174 countries pledged to work together to keep global warming well below 2 degrees Celsius by supporting more renewable energy investment. Algae are one of the very promising feedstocks for biofuel production.

\section{Algae as a renewable energy source}

The world's economic progress is heavily reliant on fossil fuel supplies, which are restricted not just in terms of availability but also due to the caused pollution. Due to the scarcity of fossil fuels and their accompanying difficulties, substantial attempts have been made to find alternative biofuels such as bioethanol and biodiesel (Rajvanshi \& Sharma, 2012; Abo-State et al., 2019; Abomohra et al., 2020). The hunt for a sustainable alternative fuel has been fueled by the depletion of fossil fuels, rising prices, rising demand, and global climate change concerns. Microalgae have emerged as a possible biofuel feedstock, since several strains accumulate more lipid, grow quicker, and produce more photosynthetic biomass yield than their land plant equivalents (Sharma et al., 2018). Algae are considered the $3^{\text {rd }}$ generation of bioenergy, which can be converted directly into biodiesel, bioethanol, and biomethanol, making it a renewable energy source (Najafi et al., 2011; El-Sheekh et al., 2018; Shanab et al., 2021). Biodiesel production from algae is gaining popularity due to its higher output of non-edible oil and rapid growth that does not compete with land for food production (Najafi et al., 2011). Transesterification of lipids to biodiesel (Chisti, 2007; El-Sheekh et al., 2013, 2017), saccharification of carbohydrates to ethanol (Matsumoto et al., 2003; Abou El-Souod et al., 2021), and gasification of biomass to syngas (Matsumoto et al., 2003) are examples of renewable, carbon-neutral fuel applications utilizing algal biomass. The residual biomass fraction of the algae after oil extraction can be used as a high protein feed for livestock and fish. Unlike biofuels made from plants, algaebased biofuels do not have harmful effects on the environment or food supply (Adeniyi et al., 2018).

The use of algae as a raw material and an excellent supply of polysaccharides that can be fermented to bioethanol is essential for the production of third-generation bioethanol. Because of its carbohydrate content, the microalga Chlorella vulgaris is suitable for bioethanol synthesis (Abou El-Souod et al., 2021). Due to their promising yield in nature and their long-term benefits over typical terrestrial feedstocks, microalgae-based biofuels are expected to provide a viable alternative to fossil fuels. They have unique metabolic properties that can be tweaked to produce sustainable

Corresponding author email: mosstafaelsheikh@science.tanta.edu.eg

Received 23/09/2021; Accepted 23/10/2021

DOI: 10.21608/ejbo.2021.97628.1795

Edited by: Prof. Dr. Salama A. Ouf, Faculty of Science, Cairo University, Giza 12613, Egypt.

C2021 National Information and Documentation Center (NIDOC) 
biofuels on a commercial scale (Sharma et al., 2018; El-Sheekh et al., 2019).

\section{Advantages of biodiesel}

Biodiesel has several advantages as compared with other fuel sources. Since the fuel is made from biomass, it does not contribute to $\mathrm{CO}_{2}$ emissions into the atmosphere. Biodiesel produces fewer emissions than petroleum diesel. When biodiesel is used instead of petroleum diesel, emissions of soot, sulphur, unburned hydrocarbons, and polycyclic aromatic hydrocarbons are significantly reduced. The infrastructure required for biodiesel production is already in place. Biodiesel can be blended with petroleum diesel up to $20 \%$ in existing diesel engines or run unblended in engines with simple changes. Biodiesel's lubricating qualities can extend engine life because it has twice the viscosity of petroleum diesel. Biodiesel has low toxicity and is biodegradable. Biodiesel has a cleaner burn and complete combustion.

\section{Future of biodiesel}

Carmakers will be expected to conform to the EU's $95 \mathrm{~g} \mathrm{CO}_{2} / \mathrm{km} \mathrm{CO}_{2}$ emissions threshold for newly marketed passenger cars starting in 2021, which implies biofuels will be one of their viable options (Hombach et al., 2016). By addressing the inherent hurdles and limits, algal fuel and bioproducts technologies can be upgraded from pilot to commercial scale (Khan et al., 2018). To increase the commercial feasibility of the global algal biofuels industry, further research is needed to produce the most energy-efficient, cost-effective, and high-yield extraction method. This will cover all of the major technological concerns that affect various manufacturing processes. As a result, when algal biofuel manufacturing becomes a commercial endeavor, government emission policies along with prior research and development will be accelerated (Hombach et al., 2016). Finally, algae can solve the lack of fossil fuel in the future through its enormous benefits for the environmental balance and the production of bioenergy.

\section{References}

Abomohra A., Elasyed M., Sakkimuthu S., ElSheekh, M., Hanelt D. (2020) Potential of fat, oil and grease (FOG) for biodiesel production: A critical review on the recent progress and future perspectives. Progress in Energy and Combustion Science, 81, 100868.
Abou El-Souod, G.W., Morsy, EM., Hassan, L., ElSheekh, M.M. (2021) Efficient saccharification of the microalga Chlorella vulgaris and its conversion into ethanol by fermentation. Iranian Journal of Science and Technology, Transactions A: Science, 45(3), 767-774.

Abo-State, Mervat A.M., Shanab, Sanaa M.M., Ali, H.E.A. (2019) Effect of nutrients and gamma radiation on growth and lipid accumulation of Chlorella vulgaris for biodiesel production. Journal of Radiation Research and Applied Sciences, 12(1), 332-342.

Adeniyi, O.M., Azimov, U., Buluka, A. (2018) Algae biofuel: Current status and future applications. Renewable and Sustainable Energy Reviews, 90, 316-335.

Chisti, Y. (2007) Biodiesel from microalgae. Biotechnology Advances, 25, 294-306.

El-Sheekh M., Abomohra, A., Hanelt, D. (2013) Optimization of biomass and fatty acid productivity of Scenedesmus obliquus as a promising microalga for biodiesel production. World Journal of Microbiology and Biotechnology, 29, 915-922.

El-Sheekh, M.M., El-Gamal, A., Bastawess, A.E., El-Bokhomy, A. (2017) Production and characterization of biodiesel from the unicellular green alga Scenedesmus obliquus. Energy_Sources, Part A: Recovery, Utilization, and Environmental Effects, 38(8), 783-793.

El-Sheekh, M.M., Abomohra, A., El-Adel, H., Battah, M., Mohammed, S. (2018) Screening of different species of Scenedesmus isolated from Egyptian freshwater habitats for biodiesel production. Renewable Energy, 129, 114-120.

El-Sheekh, M.M., Gheda, S., El-Sayed, A.B., Abo Shady, A., El-Sheikh, M., Schagerl, M. (2019) Outdoor cultivation of the green microalga Chlorella vulgaris under culture stress conditions as a feedstock for biofuel. Environmental Science and Pollution Research, 26, 18520-18532.

Hombach,, L.E., Cambero, C., Sowlati, T., Walther G. (2016) Optimal design of supply chains for second generation biofuels incorporating European biofuel regulations. The Journal of Cleaner Production, 133, 565-575. 
Khan, M.I., Shin, J.H., Kim, J.D. (2018) The promising future of microalgae: current status, challenges, and optimization of a sustainable and renewable industry for biofuels, feed, and other product. Microbial Cell Factories, 17, 36.

Matsumoto, M., Yokouchi, H., Suzuki, N., Ohata, H., Matsunaga, T. (2003) Saccharification of marine microalgae using marine bacteria for ethanol production. Applied Biochemistry and Biotechnology, 105, 247-254.

Najafi, G., Ghobadian, B., Yusaf, T.F. (2011) Algae as a sustainable energy source for biofuel production in Iran: A case study. Renewable and Sustainable Energy Reviews, 15(8), 3870-3876.
Rajvanshi, S., Sharma, M.P. (2012) Microalgae: A potential source of biodiesel. Journal of Sustainable Bioenergy Systems, 2, 49-59.

Shanab, S.M.M., Abo-State, M.A., Ali, H.A. (2021) Impact of culture media composition, nutrients stress and gamma radiation on biomass and lipid manufacture of the green microalga, Dictyochloropsis splendida as a potential feedstock for biodiesel production. Baghdad Science Journal, https://doi.org/10.21123/ bsj.2022.19.1.0043

Sharma, P.K., Saharia, M., Srivstava, R., Kumar, S., Sahoo, L-G. (2018) Tailoring microalgae for efficient biofuel production. Frontiers in Marine Science, 5, https://doi.org/10.3389/ fmars.2018.00382

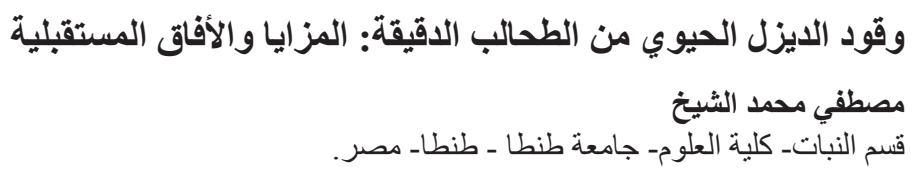

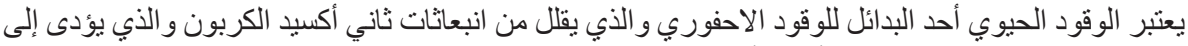

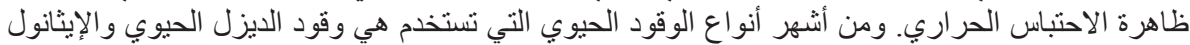

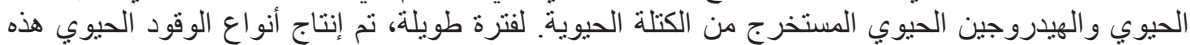

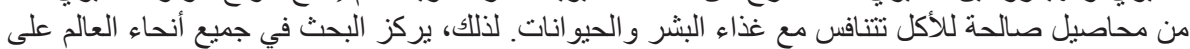

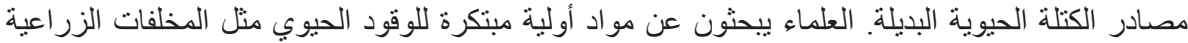

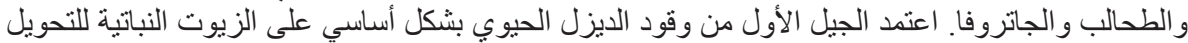

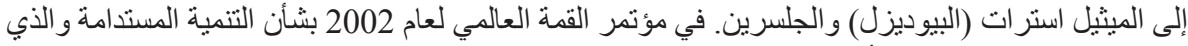

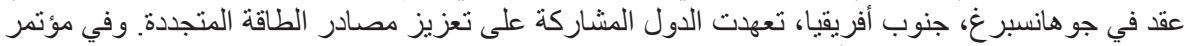

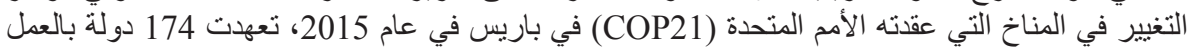

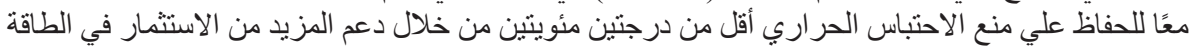

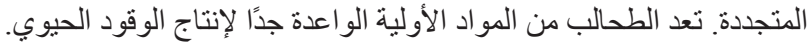

